\title{
The Challenge of Managing Government-Industry Relationships
}

\author{
—The Case of Suntech and Wuxi
}

\author{
Shi Li \\ Renmin University of China, Beijing, China \\ Email: historylee@hotmail.com
}

Received July 30 ${ }^{\text {th }}$, 2013; revised August 30 ${ }^{\text {th }}$, 2013; accepted September $7^{\text {th }}$, 2013

\begin{abstract}
Copyright (c) 2013 Shi Li. This is an open access article distributed under the Creative Commons Attribution License, which permits unrestricted use, distribution, and reproduction in any medium, provided the original work is properly cited.
\end{abstract}

\begin{abstract}
Suntech, once the star of China's PV industry, now is a highly distressed company under bankruptcy protection towards restructure of business activities. From Suntech's founding to its uncertain future prospects, the paper discussed the company's growth story as a good case study to discuss the opportunities and risks resulting from China's approach to industrial development, which is motivated by booming local economic growth. In the article, we first stated the evolution of Suntech and analyzed the risk factors which lead to the bankruptcy of Suntech under Kaplan's new risk management and risk categorization framework. A conclusion that the broader strategy of booming economy should be oriented in the healthy enterprise-growth based approach is introduced at the end of the paper.
\end{abstract}

Keywords: Suntech Wuxi Government-Industry Relationships in China System Risk

\section{A Lighthouse “Angel Investment”: Wuxi’s Case for Suntech}

A number of industry observers and journalists have suggested that the Chinese government's support of the PV industry was part of a broader strategy to boom star industries, such as re- newable energy, TMT, biotech, etc. However, looking at how the PV industry grew in China and how this growth was managed, the idea of a grand scheme overestimates the Chinese state's executive capabilities. Furthermore, it is far too simplistic because it does not consider the difficult power relationships and competition between Chinese regions and private actors. The reality of industrial development in China is much more complex and the central government's capability to oversee and influence local decision making should not be over-estimated. The way Suntech's relationship with the Wuxi local government evolved over time indicates how the Chinese specifics provide good opportunity for growth, yet at the same time also entail very specific risk characteristics.

In regard to the development of an advanced industrial base, Chinese cities and provinces are in a stiff competition against each other. The competition reaches down to the level of giving direct support to individual companies (Steven, 2009). One typical program is the city of Wuxi's Young Talents Program. It proved to be effective. When in 2000 Suntech's founder, Zhengrong Shi, began to look for opportunities to start a company in China, he was introduced to this program through Zhang Weiguo, a manager of the local government-owned Wuxi HighTech Venture Capital who funds Dr. Shi provided 2 million which includes a 1.6 million technology-joined stock along with 8 major local SOEs facilitated the rest $75 \%$ original stock for the company's formation. This was the beginning of Wuxi's relationship with Suntech. The development approach that Wuxi pioneered, local SOEs directly provided equity capital and local government led in support fund, bank loans and production factors to promising companies, became known as the Wuxi Model.

In the years after its incorporation in 2001, Suntech successfully ramped-up production. However, sales were unsatisfactory and the local government had to infuse liquidity into the company. It did so in 2003 and 2004 by signing two loans of RMB 50 million and channeling RMB 40 million worth of support fund to Suntech (Xiao Liu, 2012, http://comments.caijing.com.cn/2012-08-22/112073873.html).

When former Premier Wen Jiabao in 2005 introduced the $11^{\text {th }}$ five year plan to the public, he explicitly stated that the commercialization of renewable energy industries is a key area of development. The announcement coincided with accelerating growth of the international PV markets, especially in Europe. For the local government of Wuxi, a city in Jiangsu province, this was the starting call to improve the city's positioning within the solar industry. Local officials saw showing clear support for the new plan as beneficial to the local economy and potentially their future career prospects. Setting quantifiable goals for local government officials is an important tool for China to align regional and national aspirations. Once an official beats the benchmark numbers assigned to him, the official would be recognized as a strong leader in booming local economic and might expect a promotion within the state system. Due to the importance of this process for the future career, aspiring officials are highly compelled to beat the numbers with virtually any means at their disposal. Often, the race to deliver the right numbers by individual local officials is in disregard to any long-term consequences because the risk of being reprehended for a past decision is very low.

Also, they expected that creating a success story in Wuxi could kick-start the development of a local PV chain industry, 
further creating jobs and tax income. Suntech was eventually identified as an optimal target for government support. It read like the right story for future success. The idea of Suntech as a lighthouse investment was born; international private equity investors replaced the state-owned shareholders. It was designed to be a private-industry success story.

\section{Lopsided: A Partnership Just for Sunny Days}

With support of the wuxi government, Suntech was listed at the New York Stock Exchange by the end of 2005. The public support for the company was seen as a risk-limiting factor that attracted the private investors. The move seemed to be beneficial to all parties involved: The investors could multiply their investments, Suntech raised about $\$ 400$ million for further expansion and the government had a success to show for Yi, D. (2005) Suntech continued to expand in all directions: Production capacity, international presence and acquisitions of other technology companies. Between 2006 and 2011, the number of companies in the Jiangsu PV sector grew more than ten-fold, from 100 to 1100 . Suntech was seen as a successful catalyst for the growth of a whole industry (21 Century Business Herald, 2012).

The sunny days continued throughout 2007, before the stock peaked in December 2007 and lost over $50 \%$ of its value in the flowing months. The stock price decline reflected the looming problems overshadowing Suntech's future:

1) The Wealth Effect-Other provinces copied the Wuxi Model on a dramatic scale. The number of domestic competitors exploded. Private capital was mobilized as well.

2) Economic Stimulation Policy Influence-State-owned enterprises could also move into the sector. These companies were able to take on loans at an extremely low rate from state-owned banks because of the economic revitalization program introduced in 2008.

3) High dependence on exports-The economic crisis caused a decline of international sales and the risk of trade conflicts became evident with the EU and US governments implementing import tariffs in 2010.

The relationship between Wuxi and Suntech changed. Whereas in the early years the goals and perceptions of the future were closely aligned, the crisis caused a break and a growing misalignment between the two parties. While Suntech saw the need to slow down the expansion in light of the imminent market crisis, the government turned to pushing Suntech forward to keep up its fast expansion, ignoring the market development. The government didn't realize Suntech has become a global company which is responsible for international investors' benefits. The government's influence in the earlier stage of forming Suntech as a super angel investor and the channel of venture capitals, should be withdrawn when it was listed on stock market. The supervision role of Suntech should have been transferred to international investors.

For the relationship of Wuxi and Suntech, the rainy days had begun. Sources involved in the process indicated that Wuxi was able to continuously influence the decision-making of Suntech towards further expansion. Also, at that time the government did not yet further investigate reports of Suntech's unusual business practices or might ignored it intentionally because Suntech has became "too big to fail". On the other side of the table, the Suntech management knew that if they can keep a working relationship with Wuxi, the city would be compelled to reign-in once financial troubles arise from the crisis that the management knew was on the horizon. Wuxi's ongoing commitment was seen by the company management as a protection from the huge gamble Suntech engaged in.

A good example for the increasing distance between government and company goals occurred in 2011. Suntech's finances already were limited, nevertheless the local government proposed a "five years recreating Suntech" target. The target required Suntech to create 50,000 additional jobs within a certain time-frame, on land provided by the government. To that date, Suntech had about 20,000 employees in total. Meanwhile, Suntech management is presumed to involved in related transaction with Asia Silicon Co., Ltd. (BVI) in 2013, a Qinghai province based polysilicon company whose major shareholder is recognized as Dr. Shi.

\section{Unclear Boundaries: Suntech's Risk Factors}

The Suntech bankruptcy is recognized as a combination of many complex reasons: shrink of market, the change of foreign PV policies, overfunctioning of local government, management immorality, etc. This ambivalent power relationship with its unclear boundaries between government and private sector interests creates a number of problems: Perverse incentives and missing risk management played the key roles in creating the massive oversupply in the market. Under Kaplan's new risk categorization framework, Suntech bankruptcy could be listed in three risks categories: external risk, strategy risk and interior risk (Robert, S. K. \& Anette, M., 2012).

\section{External Risk}

External risks are risks arising from outside the company which the company cannot prevent from occurring, the company management could identify and mitigate these events to prevent the damage to the company. Sources of these risks include major economic, political events, as well as natural disasters.

Start from 2004, major countries such as US, Germany, Spain and Italy carried out policies favorable for the global PV Industry. However the emerge of financial crisis crashed down the PV industry, trade protectionism aroused in US and EU in the name of anti-dumping and anti-subsidy which breached the oversea market of Chinese PV companies including Suntech. US subsidized its renewable energy industry of 25.2 billion USD in the year of 2009.

In China, risk management is in a poor state caused by the lack of institutional memory. Perverse incentives are created if the government's quantitative goals and policies are not designed very carefully. During the early stages of the market's rapid expansion, the goal-setting by the national government and the Wuxi administration both worked in Suntech's favor. It provided the company with the necessary means to file for a public offering and to develop into a global leader. However, largely because of Suntech's impressive success, the incentive system started to work against the company. The number of competitors equally supported by other local governments rose quickly, creating the unsustainable overcapacity that crashed the market. Because officials will be posted to a specific position at a local government for a limited time only, and are measured using external benchmarks, they often do not have meaningful incentives to create long-lasting structures in their institutions. These structures would offer little or no immediate benefit to their 
often aggressive growth agenda and are of low priority.

With its constant pressure on Suntech to expand, the local government increased the company's exposure to market risk. When the risks became real and Suntech's bankruptcy was threatening the local industry and social order around Wuxi, the government had to come out and capture what is left of Suntech.

\section{Strategy Risk}

Strategy risks are risks which company voluntarily accepts based on the company's performance and strategy, which might generate a better performance and potential return. Risk-management system is a key part in operational process of modern entrepreneurship. Companies are supposed to identify and reduce the probability of the assumed risks to improve the company's performance. Strategy risks include shifts in production, market strategy, business model, corporate finance, improvement of management team.

In the case of Suntech, it became a global competitor through production-line capacity expansion, oversea market expansion and diversified productions to take risks in order to capture potential gains. The expansion of Suntech was however too ambitious without careful goal-setting: its production-line capacity increased 54 times from its first production-line put to operation in 2002 to 2007, which might took some companies 30 years. Meanwhile, Suntech completed 5 - 6 corporate market expansion by signing long-term raw material contract, setting up oversea offices, M\&A with foreign PV companies.

\section{Interior Risk}

The internal risks which arisen from within the organization, are controllable and ought to be eliminated or avoided. Examples are the risks from employees' and managers' unauthorized, illegal, unethical, incorrect, or inappropriate actions and the risks from breakdowns in routine operational processes. To be sure, companies should have a zone of tolerance for defects or errors that would not cause severe damage to the enterprise and for which achieving complete avoidance would be too costly. But in general, companies should seek to eliminate these risks since they get no strategic benefits from taking them on. A rogue trader or an employee bribing a local official may produce some short-term profits for the firm, but over time such actions will diminish the company's value.

Comparing with major PV companies in EU and US, the management of Suntech has not build up long term corporate strategy and its interior risk exposed. The founder Dr. Shi is a scientist background entrepreneur who might has limited knowledge of corporate management and somehow has a strong will of controlling Suntech. The management also realized its poor corporate management by introducing new individuals who have major multinational companies into the company however the relationship between Dr. Shi and the management collapsed. In an interview of him, he also said he would prefer to be named as an "adventurer" rather than a "scientist" or "entrepreneur". Before the Suntech bankruptcy, Suntech management is presumed to involved in related transaction with Asia Silicon Co., Ltd (BVI), a Qinghai province based polysilicon company whose major shareholder is recognized as Dr. Shi.

\section{Conclusion}

In China's wide reaching and expanding state sector, the central government makes intensive use of quantitative benchmarks to match regional officials' policy-making with national goals, short-term solutions improve these benchmarks outweigh longterm approaches. The government has still to learn how to better integrate market-based approaches in their planning framework. Until a change in these practices, the risk of unsustainable growth experiments will continue to exist.

In many cases, the existing model worked well and single company success stories could kick-start an industry. Yet, as was the case with the PV sector, the problem is to define reasonable funding levels and clear policies. Public funds were misallocated, directly damaging the industry they were supposed to support. This is mainly because of the strong direct influence that local Chinese officials have on their region's economic and social development. The government should push market-economy based instruments within a clear and transparent framework to enable a balancing of supply and demand.

\section{REFERENCES}

Steven, N. S. C. (2009). The economic system of China. Yi, D. (2005). Suntech: The triple-jump capital legend. China Business. Liu, X. (2012). Anbang: The dilemma of Suntech and LDK Solar. http://comments.caijing.com.cn/2012-08-22/112073873.html

21 Century Business Herald (2012). PV self-defense war of Jiangsu: 300 PV companies facing reshuffle. http://www.21cbh.com/HTML/2012-5-14/5ONDE3XzQzMjk5OQ.ht $\mathrm{ml}$

Robert, S. K., \& Anette, M. (2012). Managing risks: A new framework. Harvard Business Review. 